\title{
Comparison of Health Status and Macroeconomic Indicators in Organization for Economic Cooperation and Development Countries Using Multidimensional Scaling and TOPSIS
}

\author{
Ekonomik İş Birliği ve Kalkınma Örgütü Üyesi Ülkelerinde Sağlık Statüsü ve Makroekonomik \\ Göstergelerin Çok Boyutlu Ölçekleme ve TOPSIS ile Karşılaştırılması
}

\author{
S. Haluk ÖZSARI ${ }^{1}$ (D), Canser BOZ ${ }^{2}$ iD
}

\begin{abstract}
Objective: The relationship between health level (status) and economic level is an important research area in health economics literature, and countries with above-average health status indicators that have healthy economic indicators as well are generally accepted. The aims of the present study were to determine the position of countries based on their health status and economic indicators, to rank the performance of countries with respect to both groups of indicators, to observe the changes in and the relationship between health and economic performance ranking, and to examine the relationship between health and macroeconomic performance scores using correlation analysis.
\end{abstract}

Materials and methods: Multidimensional scaling was used to determine the countries' position, and the Technique for Order of Preference by Similarity to Ideal Solution method was used to rank the country's net performance according to health status and economic indicators. The study uses horizontal data for 2016. Economic data were obtained from the International Monetary Fund, and each of the country's health status indicators was obtained from the World Health Organization and Organisation for Economic Co-operation and Development (OECD) Health Data Bank.

Results: Macroeconomic performance ranking results showed that while Ireland performed best, Turkey performed worst among OECD countries. Health status performance ranking results ranked Japan as first and Turkey as last. Additionally, a positive, moderately significant correlation between macroeconomic and health status indicators was obtained.

Conclusion: Currently, especially with aging populations, various problems have arisen in the health status of societies, affecting the general level of health in the society and economic structure. Therefore, health services for the elderly can play a role in improving health status and economic level.

Keywords: Health status, TOPSIS, Health success, Economic performance, OECD

ÖZ

Amaç: Ülkelerin ekonomik ve sağlık durumu açısından performansları incelendiğinde sağlık durumu göstergeleri açısından başarılı olan ülkelerin genellikle ekonomik göstergeler açısından göreceli olarak başarılı olduğu görülmektedir. Bu doğrultuda, bu çalışmanın amacı, ülkelerin hem sağlık durumu hem de ekonomik göstergeleri açısından birbirlerine göre konumlarını belirlemek, her iki gösterge grubu açısından ülkelerin performans sıralamasını yapmak, sağlık ve ekonomi performans sıralaması arasındaki ilişki ve değişimleri gözlemlemek ve aradaki ilişkiyi incelemektir.

Gereç ve Yöntem: Çalışmada ülkelerin birbirlerine göre konumlarını belirlemek için Çok Boyutlu Ölçeklendirme (MDS) yöntemi, sağlık durumu ve ekonomik göstergelere göre net performans sıralamasında ise TOPSIS yöntemi kullanıldı. Araştırmada kullanılan veriler 2016 yılı veya en yakın yatay verilerdir. Ekonomik veriler Uluslararası Para Fonu'ndan (IMF-2016) alınmış ve Dünya Sağlık Örgütü ve OECD Sağlık Veri Bankası'ndan ise sağlık göstergeleri elde edilmiştir.

Bulgular: TOPSIS yöntemi yardımı ile Makroekonomik performans sıralamasında elde edilen sonuçlara göre, İrlanda 34 OECD ülkesi içinde en iyi performansa sahip ülke, Türkiye 34 OECD ülkesinde en kötü performansa sahip ülke olarak bulunmuştur.

Received/Geliş Tarihi: 23.09.2018 Accepted/Kabul Tarihi: 19.06.2019 Çevrimiçi Yayın Tarihi/Available Online Date: 23.09.2019 ${ }^{1}$ Acıbadem Mehmet Ali Aydınlar Üniversitesi, Sağlık Bilimleri Fakültesi, Sağlık Yönetimi Bölümü, İstanbul, Türkiye ${ }^{2}$ İstanbul Üniversitesi-Cerrahpaşa, Sağlık Bilimleri Fakültesi, Sağlık Yönetimi Bölümü, Sağlık Ekonomisi Anabilim Dalı, İstanbul, Türkiye

Correspondence/Sorumlu yazar: Canser BOZ, İstanbul Üniversitesi-Cerrahpaşa, Sağlık Bilimleri Fakültesi, , Sağlık Yönetimi Bölümü, Sağlık Ekonomisi Anabilim Dalı, İstanbul, Türkiye, canser.boz@istanbul.edu.tr

Cite this article as: Özsarı H, Boz C. Comparison of Health Status and Macroeconomic Indicators in Organization for Economic Cooperation and Development Countries Using Multidimensional Scaling and TOPSIS. Journal of Health Science and Profession 2019; 6(3): 545-54. 
Sağlık statüsü performans sıralamasına göre ise Japonya, 34 OECD ülkesi arasında ilk ülke iken, Türkiye yine en son sırada yer almıştır. Ayrıca ülkelerin makro-ekonomik göstergelerin TOPSIS başarı puanları ile sağlık durumu göstergelerinin başarı puanları arasında orta derecede istatistiksel olarak anlamlı pozitif yönlü bir ilişki gözlemlenmiştir.

Sonuç: Günümüzde özellikle toplumun yaşlanması ile birlikte toplumların sağlık statüsünde çeşitli sorunlar ortaya çıkmaktadır. $\mathrm{Bu}$ durum hem toplumun genel sağlık seviyesini hem de genel ekonomik yapısını etkilemektedir. Bu nedenle sağlık statüsünün geliştirilmesi noktasında sağlık hizmetlerinin, hem sağlık statüsünü geliştirme hem de ekonomik düzeyi iyileştirmede rol oynayabileceğini söylenebilir.

Anahtar Kelimeler: Sağlık Durumu, TOPSIS, Sağlık Başarıları, Ekonomik Performans, OECD

\section{Introduction}

The World Health Organization (WHO) defines "health" as a state of complete physical, mental, and social well-being and not merely the absence of diseases and infirmity (1). It also defines health services, both personal and non-personal, as services dealing with the diagnoses and treatment of disease or the promotion, maintenance, and restoration of health. Health services are the most visible function of any health system to both users and the general public (2). The ultimate goal of all health systems is to protect and improve the health status of the individual and the community, and this is why many countries have been recently implementing reforms in their health care systems. Various indicators are used to measure health status; these are called general health status indicators and include many factors, such as life expectancy, and mortality and morbidity rates of various diseases. The Healthy People 2010 goals states that eliminating health disparities and improving health status factors, such as the length and quality of life, are among the main objectives of any health system worldwide. Thus, these objectives have become the central focus of many public activities that increase emphasis on community-based approaches to health improvement (3).

Currently, countries seeking to attain "developed" status or a certain level of prosperity allocate greater resources each year to their health services to improve the health status of the community. Further, countries are increasing resource allocation from their gross national product to both maintain and improve human health and the treatment of diseases, which are the main elements of economic development, as investments in health are considered "productive investments." Thus, it is generally accepted in the literature that if countries show sufficient health status, they will also enjoy relatively well-performing economic indicators (4).
Studies have been conducted in specific areas of development, education, and health covered by the theory of human capital, and in this context, the literature has expanded. According to this theory, healthy individuals are better educated and comprise the qualified human power necessary for development. Therefore, education and health are regarded as human capital investment, and it is also necessary to invest in health education. Concurrently, indicators, such as infant mortality rate and life expectancy, are also strongly associated with per capita national income (5).

There is a mutual relationship between economic development and health status. Increasing per capita income leads to increased health spending and improved health status. As economic performance is associated with health status, improvements in health positively affect labor supply, per capita income, and growth rates in both quantity and quality. Sachs (6) summarized the contribution of health to economic development and the development process. The author stated that the most important economic impact of health is seen on human and venture capital. Health is influenced by previous economic policies and institutions and affects human capital and the technological level of society, resulting in an increase in per capita income and a reduction in poverty.

Health as a human capital investment directly affects individuals and their social life; on the other hand, it also directly and indirectly influences economic performance through investment, employment, and production and contributions to the quality of the labor force (7).

The relationship between health level and economic level is one of the main research areas in the literature. It is generally accepted that countries that perform well with respect to health status indicators are also relatively successful with respect to eco- 
nomic indicators when the performance of countries with respect to economic performance and health status is examined. Published studies show that the relationship between mortality rate or life expectancy and economic growth is generally considered as time series or panel data for a certain period, and the relationship between health and economic success is thereby examined. In the present study, the relationship between economic performance and health performance was examined in a broader context by using more than one variable and country so that both economic success and health performance of a country may be measured more accurately.

The aims of the present study were to determine the position of countries based on health status and economic indicators, to establish the performance ranking of countries with respect to both, to observe the changes between health and economic performance ranking, and to examine the relationship between health status and economic performance of Organisation for Economic Co-operation and Development (OECD) countries.

\section{Materials and Methods}

Multidimensional scaling (MDS) was used to determine a countries' position, and the Technique for Order of Preference by Similarity to Ideal Solution (TOPSIS) method, which is a type of multi-criteria decision-making technique, was used to calculate the net performance ranking of countries according to health status and macroeconomic indicators.

MDS is a statistical method for revealing the relationship between objects using distances between them, especially in cases where the relationships between objects are not known, but the distances between them can be calculated $(8,9)$. It is a technique of interdependence that is used when any or all variables of a group are not dependent on one another but cannot be explained by another either, or when investigators are interested in the mutual relationship among all variables. There are complicated mathematical, geometric, and statistical operations that can produce models that visually reveal the structure of the variable $(8,10)$.

The MDS method uses the distance matrix, and it is important to calculate this matrix based on data type. If data are spaced or proportionally scaled, the difference matrix can be calculated as Euclidean, Quadratic Euclidean, Block, Minkowski, Chebyshev, or customized distances. Euclidean and Quadratic Euclidean distances $(n * p)$ are a dimension of a data matrix, and $\mathrm{j}$ is a measure that determines the distances between units directly in the unit of measurement or in the form of Quadratic distances. Euclidean distances are $\mathrm{i}$ and $\mathrm{j}$. The squares of the differences of the units are obtained using the square root of the sum of the differences (9).

The desired solution in MDS is a solution in three or fewer dimensions. Thus, a graphical representation is obtained that includes the traceable and the explorable forms of units and objects. In addition, the desired stress statistic in the MDS solution is close to zero.

TOPSIS is a multi-criteria decision-making technique that is used for ranking countries using macroeconomic indicators.

The TOPSIS method was developed by Hwang and Yoon in 1981 as a multi-criteria decision-making technique (11). The positive-ideal solution for the TOPSIS method is based on the shortest distance and a negative-ideal solution to the longest distance (12). A 6-step guide is provided for implementing the TOPSIS method (Table 1) (13).

\section{Statistical analysis}

Data used in the present study are horizontal data for 2016. Macroeconomic indicators include gross domestic product (GDP) (0.2567), total investment (0.0423), gross national savings $(0.0145)$, inflation (0.149), volume of imports of goods and services $(0.0585)$, volume of exports of goods and services (0.0856), unemployment rate $(0.120)$, general government revenue $(0.0185)$, general government total expenditure $(0.0257)$, general government gross debt (0.0356), and current account balance (0.1936). Health status indicators include life expectancy at birth, satisfaction from health services, neonatal mortality rate (per 1000 live births), maternal mortality rate (per 100,000 live births), age-standardized mortality rate for cardiovascular diseases (per 100,000 population), age-standardized mortality rate for cancer (per 100,000 population), age-standardized mortality rate for diabetes (per 100,000 population), and age-standardized mortality rate 
Table 1. Application steps of the TOPSIS method

Step 1: Creating the decision matrix (A)

$$
\boldsymbol{A}_{i j}=\left[\begin{array}{cccc}
a_{11} & a_{12} & \ldots & a_{1 n} \\
a_{21} & a_{22} & \ldots & a_{2 n} \\
\cdot & & & \cdot \\
\cdot & & & \cdot \\
\cdot & & & \cdot \\
a_{m 1} & a_{m 2} & \ldots & a_{m n}
\end{array}\right]
$$

Step 2: Creating the standard decision matrix $(\mathrm{R})$

$$
r_{i j}=\frac{a_{i j}}{\sqrt{\sum_{k=1}^{m} a_{k j}^{2}}} R_{i j}=\left[\begin{array}{cccc}
r_{11} & r_{12} & \ldots & r_{1 n} \\
r_{21} & r_{22} & \ldots & r_{2 n} \\
\cdot & & & \cdot \\
\cdot & & & \cdot \\
\cdot & & & \cdot \\
r_{m 1} & r_{m 2} & \ldots & r_{m n}
\end{array}\right]
$$

Step 3: Creating the weighted standard decision matrix (V)

First, the weight values ( ) of the evaluation factors are determined

$$
\sum_{i=1}^{n} w_{i}=1 \quad V_{i j}=\left[\begin{array}{cccc}
w_{1} r_{11} & w_{2} r_{12} & \ldots & w_{n} r_{1 n} \\
w_{1} r_{21} & w_{2} r_{22} & \ldots & w_{n} r_{2 n} \\
\cdot & & & \cdot \\
\cdot & & & \cdot \\
\cdot & & & \cdot \\
w_{1} r_{m 1} & w_{2} r_{m 2} & \ldots & w_{n} r_{m n}
\end{array}\right]
$$

Step 4: Creating ideal and negative-ideal solutions

$$
\begin{aligned}
& A^{*}=\left\{\left(\max _{i} v_{i j} \mid j \in J\right),\left(\min _{i} v_{i j} \mid j \in J^{\prime}\right\}\right. \\
& A^{-}=\left\{\left(\min _{i} v_{i j} \mid j \in J\right),\left(\max _{i} v_{i j} \mid j \in J^{\prime}\right\}\right.
\end{aligned}
$$

Step 5: Calculation of the separation measures

$$
\begin{aligned}
& S_{i}^{*}=\sqrt{\sum_{j=1}^{n}\left(v_{i j}-v_{j}^{*}\right)^{2}} \\
& S_{i}^{-}=\sqrt{\sum_{j=1}^{n}\left(v_{i j}-v_{j}^{-}\right)^{2}}
\end{aligned}
$$

Step 6: Calculation of the ideal solving relative proximity

$$
C_{i}^{*}=\frac{S_{i}^{-}}{S_{i}^{-}+S_{i}^{*}}
$$

Source: Created by the authors with reference to Yıldırım and Önder (2015).

for chronic respiratory diseases (per 100,000 population). Economic data were obtained from the International Monetary Fund database (14), and data on health status indicators were gained from the WHO and OECD health data bank for each country $(2,15)$. In addition, values in parentheses represent the weight of the indicators to be used in the TOPSIS net performance analysis. The criteria priority weights have been taken from Onder et al. (16), wherein they have used the analytical network 
process to determine the weights of macroeconomic indicators and are based on expert judgments. In contrast, the weights of all health status indicators are considered to be equal.

\section{Results}

Performance rankings were given primarily according to macroeconomic and health status indicators for OECD countries. The results of the analysis with multi-criteria decision-making techniques and the TOPSIS method are shown in Table 2.

According to these macroeconomic performance ranking results, Ireland performed best, whereas Turkey performed the worst among the 34 OECD countries based on the present study's variables. Performance ranking based on health indicators ranked Japan as first, whereas Turkey was ranked last among the 34 OECD countries.

The most notable countries are Hungary, New Zealand, and France when the health performance ranking and the macroeconomic performance ranking of countries are compared. Hungary ranks 32nd among the 34 countries in health status and $11^{\text {th }}$ in economic performance; hence, Hungary has the highest absolute value difference with respect to the two rankings. Another striking result of the present study is Turkey. Turkey was ranked last $\left(34^{\text {th }}\right)$ in both health status and macroeconomic performance. Thus, Turkey has the lowest absolute value difference with respect to the two rankings. Moreover, Germany, Austria, Mexico, Portugal, and the Slovak Republic have similar rankings for both health status and macroeconomics performance (max difference 2; Table 2).

The positions of countries according to their macroeconomic and health status indicators are based on the results of the MDS, which is a multivariate statistical technique. The results of the MDS analysis for macroeconomic performance are shown on the left, and the results of the MDS analysis for health status indicators are shown on the right. The effectiveness of MDS analysis is mea- sured by the Kruskal stress test using the Kruskal stress statistic; the ratio of the difference between the configuration measurement and the estimated configuration measurement to the estimated configuration distances is calculated as a square root and refers to the fit between the data distances and the configuration distances (8).

The iteration was continued as $\mathrm{k}=2$ (Kruskal) until the stress statistic was $<0.001$ in the analysis for macroeconomic indicators. The iteration was terminated because the $6^{\text {th }}$ iteration yielded a stress statistic of 0.00079 , which is very close to zero. This is a desirable result for MDS analysis.

The stress value was calculated according to Kruskal's formula and was found to be 0.86362 . In this context, the stress value for $\mathrm{k}=2$ is explained by 0.86 . The iteration was terminated after 4000 steps in the analysis for health status indicators. Stress value was also calculated according to Kruskal's formula and was found to be 0.84811 . In this context, stress value data for the $\mathrm{k}=2$ dimension is explained by 0.84 .

The model on the left side (Figure 1) is for Greece, which is separated from other countries with respect to macroeconomic indicators. In addition to Greece, Turkey (Var23) ${ }^{1}$ appears to diverge from the cluster of other countries that are closer together. Although there are multiple possible weights in the TOPSIS analysis, the results of the MDS analysis are similar to the TOPSIS performance results. The right-side panel (Figure 2) depicts the most diversified countries according to their health status indicators, and these include Turkey, Mexico, Hungary, and Chile. Turkey was found to be the most diversified country among the 34 countries and is in line with the TOPSIS results. Another noteworthy aspect of MDS results is that countries are more scattered and distant from each other in their health status indicators than in their macroeconomic indicators, and this is due to the fact that there is more variability in health indicators.

1 Var1: United States, Var2: Switzerland, Var3: Germany, Var4: France, Var5: Iceland, Var6: Belgium, Var7: Greece, Var8: Portugal, Var9: Canada, Var10: Norway, Var11: Australia, Var12: Austria, Var13: Netherlands, Var14: Sweden, Var15: Denmark, Var16: Italy, Var17: New Zealand, Var18: Hungary, Var19: United Kingdom, Var20: Spain, Var21: Japan, Var22: Luxembourg, Var23: Turkey, Var24: Czech Republic, Var25: Ireland, Var26: Mexico, Var27: Poland, Var28: Slovak Republic, Var29: South Korea, Var30: Estonia, Var31: Israel, Var32: Chile, Var33: Slovenia, Var34: Finland. 
Table 2. Macroeconomic and health status performance rankings

\begin{tabular}{|c|c|c|c|c|c|}
\hline Countries & $\begin{array}{c}\text { Macroeconomic } \\
\operatorname{rank}(\mathrm{I})\end{array}$ & $\begin{array}{l}\text { TOPSIS } \\
\text { score }\end{array}$ & $\begin{array}{c}\text { Health status } \\
\operatorname{rank}(J)\end{array}$ & $\begin{array}{l}\text { TOPSIS } \\
\text { score }\end{array}$ & $\begin{array}{c}\text { Rank difference } \\
(\mathbf{I}-\mathbf{J})\end{array}$ \\
\hline Australia & 22 & 0.434 & 8 & 0.764 & 14 \\
\hline Austria & 12 & 0.544 & 13 & 0.746 & -1 \\
\hline Belgium & 18 & 0.466 & 10 & 0.759 & 8 \\
\hline Canada & 28 & 0.381 & 17 & 0.733 & 11 \\
\hline Chile & 29 & 0.380 & 33 & 0.408 & -4 \\
\hline Czech Republic & 16 & 0.498 & 19 & 0.722 & -3 \\
\hline Denmark & 7 & 0.642 & 22 & 0.673 & -15 \\
\hline Estonia & 20 & 0.450 & 23 & 0.673 & -3 \\
\hline Finland & 21 & 0.449 & 2 & 0.834 & 19 \\
\hline France & 24 & 0.431 & 5 & 0.807 & 19 \\
\hline Germany & 6 & 0.681 & 7 & 0.771 & -1 \\
\hline Greece & 33 & 0.355 & 26 & 0.645 & 7 \\
\hline Hungary & 11 & 0.549 & 32 & 0.464 & -21 \\
\hline Iceland & 14 & 0.531 & 4 & 0.823 & 10 \\
\hline Ireland & 1 & 0.758 & 11 & 0.756 & -10 \\
\hline Israel & 15 & 0.514 & 25 & 0.657 & -10 \\
\hline Italy & 17 & 0.478 & 14 & 0.742 & 3 \\
\hline Japan & 13 & 0.539 & 1 & 0.876 & 12 \\
\hline Korea & 8 & 0.622 & 24 & 0.668 & -16 \\
\hline Luxembourg & 2 & 0.744 & 16 & 0.734 & -14 \\
\hline Mexico & 30 & 0.377 & 31 & 0.485 & -1 \\
\hline Netherlands & 5 & 0.687 & 20 & 0.713 & -15 \\
\hline New Zealand & 31 & 0.377 & 12 & 0.756 & 19 \\
\hline Norway & 4 & 0.720 & 21 & 0.699 & -17 \\
\hline Poland & 23 & 0.434 & 29 & 0.608 & -6 \\
\hline Portugal & 25 & 0.411 & 27 & 0.634 & -2 \\
\hline Slovak Republic & 26 & 0.409 & 28 & 0.631 & -2 \\
\hline Slovenia & 9 & 0.609 & 6 & 0.799 & 3 \\
\hline Spain & 19 & 0.455 & 15 & 0.739 & 4 \\
\hline Sweden & 10 & 0.607 & 3 & 0.829 & 7 \\
\hline Switzerland & 3 & 0.734 & 9 & 0.763 & 6 \\
\hline Turkey & 34 & 0.264 & 34 & 0.316 & 0 \\
\hline United Kingdom & 32 & 0.361 & 18 & 0.730 & 14 \\
\hline United States & 27 & 0.403 & 30 & 0.554 & 3 \\
\hline
\end{tabular}


Table 3. Correlation analysis

\begin{tabular}{llcc}
\hline & & Macroeconomics & Health status \\
\hline TOPSIS macroeconomics & Pearson correlation & 1 & $0.425^{*}$ \\
& Sig. (2-tailed) & & 0.012 \\
& $\mathrm{~N}$ & 34 & 34 \\
\hline
\end{tabular}

*Correlation is significant at the 0.05 level (2-tailed).

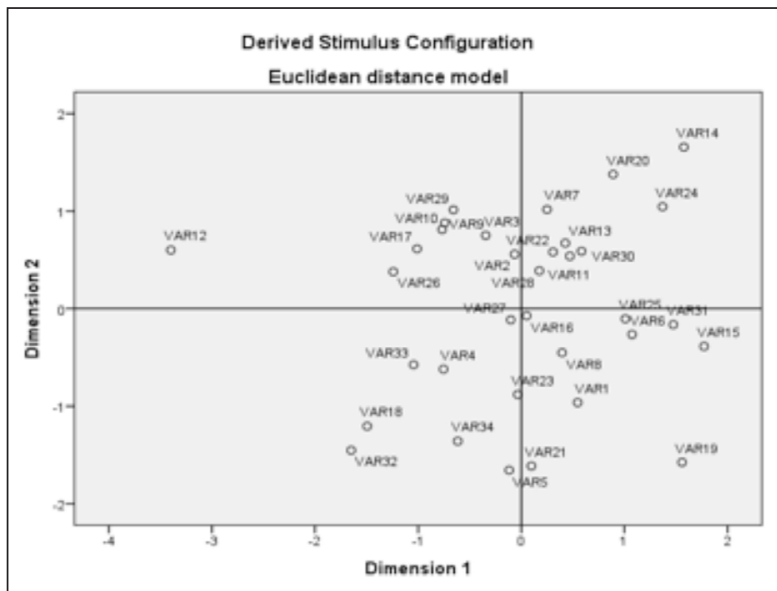

Figure 1. Euclidean distance model (macroeconomic)

Finally, the relationship between above-average health indicators and economic success has been examined in the present study. The TOPSIS health status and the TOPSIS macroeconomic scores of the countries for the variables were used, and the results of the correlation analysis are shown in Table 3.

Pearson correlation analysis showed that there was a positive, mean, and moderately significant correlation between the success scores of macroeconomic indicators and the achievement scores of health status indicators $(\mathrm{p}<0.05)$, implying the presence of the relationship between health indicators and economic success.

\section{Discussion}

Health performance and economic performance are interlinked, and wealthier countries have healthier populations from the beginning. Further, poverty, mainly through infant malnourishment and mortality, is known to adversely affect life expectancy. National income has a direct effect on the development of health systems, mainly through insurance coverage and public spending. As demonstrated

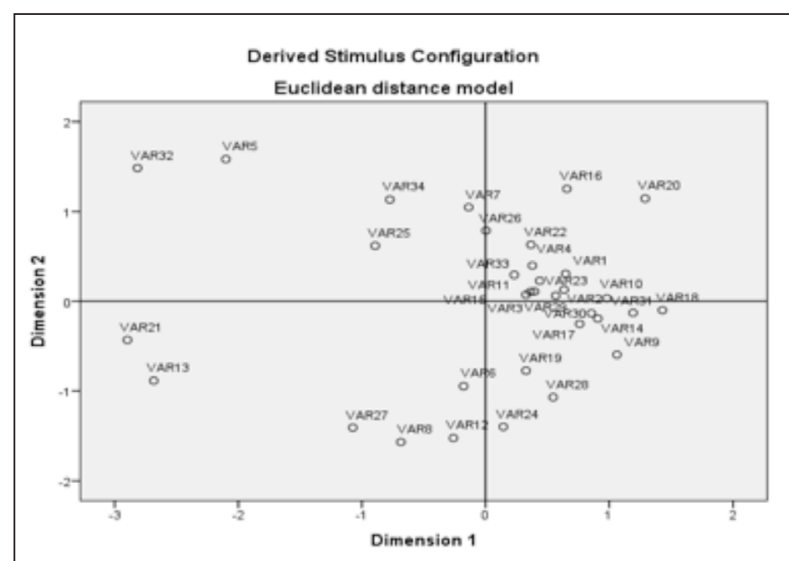

Figure 2. Euclidean distance model (health status)

in 1997 by the 167 country WHO Commission on Macroeconomics and Health, while health expenditures are determined mainly by national income, they increase faster than income (17). Therefore, the aims of the present study were to determine the position of countries based on both health status and economic indicators, to rank the performance of countries with respect to both groups of indicators, and to observe the changes in and the relationship between health and economic performance rankings.

The TOPSIS performance score yeilded a moderate, significant, and positive relationship between health performance and economic performance in OECD countries. This moderate relationship between success in health indicators and economic indicators is the result of health status being influenced by many factors, such as structural characteristics of the health system, social structure, cultural habits, work and living conditions, genetic structure, and economic success. The most striking countries are Finland, France, and New Zealand as their health performance rankings are 19 points 
higher than their economic rankings according to the TOPSIS performance scores. Finlands' situation is especially striking as its economic performance ranking is 21 , whereas its health performance ranking is 2, only behind Japan. Finland is a good example of many factors that influence the level of health in a country in addition to the economy. Another remarkable point observed in our results is the order of Hungary, Korea, and Norway. While these countries are relatively better off with respect to macroeconomics than other countries, their health performance rankings lag behind other countries. As one of the world's most prosperous countries, Norway has a macroeconomic performance ranking of 4, whereas its health performance ranking is 21. This is an example of the fact that economic success alone is not sufficient to achieve adequate health status. Similarly, even though the evidence shows a clear two-way linkage between health and growth, improved health outcomes alone are not sufficient for sustained high economic growth and performance; education, strong macroeconomic policies, and efficient institutional set-ups are equally significant. Nonetheless, improving public health can also be an important tool for reducing poverty (18).

Another remarkable study result is the state of Turkey. Turkey is a country that has made significant reforms and improvements in health in recent years. Compared with 2002, the life expectancy in Turkey increased by approximately $6.5 \%$, whereas the infant mortality rate decreased by approximately $62 \%$. Turkey still ranked last with respect to health status indicators among all 34 countries compared with other OECD countries. There can be two main reasons for this obsedrvation. First, Turkey's progress rate for health status indicators remains lower than other OECD countries; second, despite significant progress in Turkey's health status indicators in recent years, there is a large difference in health status indicators compared with other countries, which is a carry-over from the past. The second reason is more valid, because Turkey's recorvery rate is higher than the percentage of health status indicators in many OECD countries. However, Turkey still ranks last with respect to health performance owing to the intial difference in health status. This is an indica- tion that there is still much work to be done under Turkey's Health Transformation Program, which aims to improve the health status of the Turkish population. A similar situation applies to Turkey's macroeconomic indicators. Interestingly, Turkey has the least difference with respect to performance ranks for macroeconomic performance and health performance among OECD countires as the difference between ranks is zero.

\section{Conclusion}

Improving the health status of the society and ensuring that the citizens live under economically prosperous conditions are among the priority objectives of the countries' programs today. In aging populations, various health status problems are known to arise, and countries need to allocate a significant part of their resources to this issue. It has been revealed that health expenditures have increased with an increase in aging, and according to the results of the present study, there is a relationship between health status indicators that are influenced by many factors, such as aging, individual lifestyle, general education level, early age, and the economic performance of countries; however, there are some exceptions. Aging is one of the main determinants of health status, even though this was not used in the current study. Aging as a factor implies that the problem of an aging society will not only lead to issues with health status in the coming years but also affect economic and social well-being. At this point, it can be said that health services for the people and any effort to increase the level of public health consciousness would play a role in improving health and economic status.

Health is a key component of individual and social well-being. The health of a population is a key driver of labor and capital investment and consequent economic success. Good health can lead to higher GDP per capita in the long run due to its impact on the population and its participation and productivity. On the other hand, health status is primarily determined by biomedical, lifestyle, and socio-economic factors, such as economic success. Thus, there is evidence for health and economic performance being interlinked, and the impact of health on the economy and vice versa should not 
be underestimated. The challenge is to harmonize health and economic policies to improve health outcomes and economic performance. Therefore, evidence from international studies in this area will contribute to a better understanding of a very broad concept, namely health and economy.

Ethics Committee Approval: Ethics committee approval was not received for this study since the article does not contain any application on human participants or animals performed by any of the authors.

Informed Consent: Written informed consent was not obtained because the study use secondary data and no application on the patient.

Peer-review: Externally peer-reviewed.

Author Contributions: Concept - S.H.Ö., C.B.; Design - S.H.Ö., C.B.; Supervision - S.H.Ö., C.B.; Resources - S.H.Ö., C.B.; Materials - S.H.Ö., C.B.; Data Collection and/or Processing - S.H.Ö., C.B.; Analysis and/or Interpretation - S.H.Ö., C.B.; Literature Search - S.H.Ö., C.B.; Writing Manuscript - S.H.Ö., C.B.; Critical Review - S.H.Ö., C.B.; Other - S.H.Ö., C.B.

Conflict of Interest: The authors have no conflicts of interest to declare.

Financial Disclosure: The authors declared that this study has received no financial support.

Etik Komite Onayı: Bu çalışma için etik komite onayı alınmamıştır. Çünkü bu makalede ikincil verilerden yaralanılmış ve insan ya da hayvan üzerinde herhangi bir işlem yapılmamıştır.

Hasta Onamı: $\mathrm{Bu}$ çalışmada ikincil verilerden yaralanıldığı ve hasta üzerinde herhangi bir uygulama yapılmadı $\breve{1} 1$ için hasta onamı bulunmamaktadır.

Hakem Değerlendirmesi: Dış bağımsız.

Yazar Katkıları: Fikir - S.H.Ö., C.B.; Tasarım - S.H.Ö., C.B.; Denetleme - S.H.Ö., C.B.; Kaynaklar - S.H.Ö., C.B.; Malzemeler - S.H.Ö., C.B.; Veri Toplanması ve/ veya İşlemesi - S.H.Ö., C.B.; Analiz ve/veya Yorum S.H.Ö., C.B.; Literatür Taraması - S.H.Ö., C.B.; Yazıyı Yazan - S.H.Ö., C.B.; Eleştirel İnceleme - S.H.Ö., C.B.; Diğer - S.H.Ö., C.B.
Çıkar Çatışması: Yazarlar çıkar çatışması bildirmemişlerdir.

Finansal Destek: Yazarlar bu çalışma için finansal destek almadıklarını beyan etmişlerdir.

\section{References}

1. Goldsmith S. The status of health status indicators. Health Services Report. 1972; 87(3): 212-20. [CrossRef]

2. orld Health Organization.World health organization countries data. 2015. [Internet] Available from: http://www.who.int/countries/en/ Accessed: 15.06.2018

3. Metzler M, Kanarek N, Highsmith K, Straw R, Bialek R, Stanley J, et al. Community health status indicators project: the development of a national approach to community health. Prev Chronic Dis. 2008; 5(3): A94.

4. Tokgöz E. Health in Social Development. 1st edition, Dpt Publications, Ankara 1981, pp. 499-500.

5. Şimşek M. Context of Human Capital and Brain Drain Turkey: A Comparative Analysis. 1st edition, Ekin Bookstore, Bursa 2006 (In Turkish).

6. Sachs JD. Makroeconomic and health: investing in health for economic development, report of the commission on makroeconomic and health. World Health Organization 2001 Dec 20. [Internet] Available from: http://apps.who.int/iris/handle/10665/42463 Accessed: 27.08.2018

7. Bayraktutan Y, Pehlivanoğlu F. Efficiency analysis in health establishments: kocaeli example, Kocaeli University Journal of Social Sciences Institute. 2012; 23(1): 127-62.

8. Kalaycı S. SPSS Applied Multivariate Statistical Techniques. 6th edition, Asil Publishing, Ankara 2014. (In Turkish)

9. Ersoz F. Analysis of health status and health expenditures of oecd countries and Turkey. Statisticians Journal. 2008; 2: 95-04.

10. Erol H, Özdemir A. Health reforms in Turkey and evaluation of health expenditure. Social Security Journal. 2014; 4: 9-34.

11. Shyjith K, Ilangkumaran M, Kumanan S. Multi-criteria decision-making approach to evaluate optimum maintenance strategy in textile industry. Journal of Quality in Maintenance Engineering. 2008; 14(4): 375-86. [CrossRef]

12. Monjezi M, Dehghani H, Singh TN, Sayadi AR, Gholinejad A. Application of topsis method for selecting the most appropriate blast design. Arabian Journal Of Geosciences. 2010; 5(1): 95-101. [CrossRef] 
13. Yıldırım BF. Topsis, In Önder E. Yıldırım BF (Eds). Multi Criteria Decision Making Methods. 1st edition, Dora, Bursa, 2014, pp 133-53.

14. Intarnational Monetary Fund- IMF. World economic outlook database 2016 edition. 2016. [Internet]., Avaiable from: http://www.imf.org/external/pubs/ft/ weo/2016/02/weodata/index Accessed: 15.06.2018

15. Organisation for Economic Co-operation and Development- OECD. OECD health data. 2016. [Internet]. Avaiable From: http://www.oecd.org/els/health-systems/health-data.htm Accessed: 16.06.2018
16. Onder E, Tas N, Hepsen A. Economic performance evaluation of fragile 5 countries after the great recession of 2008-2009 using analytic network process and topsis methods. Journal Of Applied Finance And Banking. 2015; 5(1): 1-17.

17. Frenk J. Health and the economy: a vital relationship. OECD. 2004 May 243. [Internet]. Avaiable From: http://oecdobserver.org/news/archivestory.php/ aid/1241/Health_and_the_economy:_A_vital_relationship_html Accessed: 27.08 .2018

18. Babatunde MA. The relationship between health and economic growth in Nigeria. Africaportal. 2012; 1(1): 1-8. 